\title{
Radioactivity at the Copper Creek Copper Lode Prospect, Eagle District, East-Central Alaska
}

\section{Trace Elements Investigations Report 195}

UNITED STATES DEPARTMENT OF THE INTERIOR U.S GEOLOGICAL SURVEY 
Geology - Mineralogy

This document consists of 10 pages。 Series A

\section{UNITED STATES DEPARTMENT OF THE INTERIOR \\ $\checkmark$ U.S. GEOLOGICAL SURVEY}

\section{RADIOACTIVITY AT THE COPPER CREEK COPPER LODE PROSPECT,}

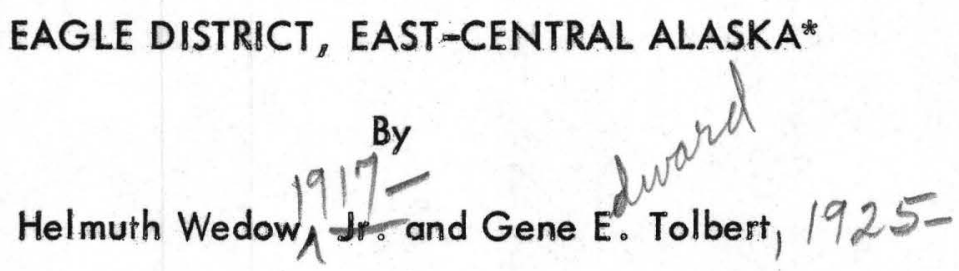

September 1952

Trace Elements Investigations Report 195

This preliminary report is distributed without editorial and technical review for conformity with official standards and nomenclature. It is not for public inspection of quotation.

*This report concerns work done on behalf of the Division of Raw Materials of the U.S. Atomic Energy Commission 
USGS - TEI Report 195

GEOLOGY - MINERALOGY

Distribution (Series A)

No. of copies

American Cyanamid Company, Watertown .......... 1

Argonne National Laboratory ................... 1

Atomic Energy Commission, Washington .......... 2

Carbide and Carbon Chemicals Company, Y $\rightarrow-12$ Area ...... 1

Colorado Raw Materials Office ( $F$. $H$. MacPherson) . ...... 1

Division of Raw Materials, Grand Junction . ......... 1

Division of Raw Materials, Grants ............. 1

Division of Raw Materials, Denver .............. 1

Division of Raw Materials, Hot Springs ........... 1

Division of Raw Materials, New York ...........6 6

Division of Raw Materials, Salt Lake City ........... 1

Division of Raw Materials, Richfield ............. 1

Division of Raw Materials, Butte .............

Division of Raw Materials, Washington .........8 8

Dow Chemical Company, Pittsburg .............. 1

Technical Information Service, Oak Ridge .........6 6

Battelle Memorial Institute, Columbus .............. 1

Tennessee Valley Authority, Wilson Dam ............ 1

U. S. Geological Survey:

Mineral Deposits Branch, Washington ............ 1

Geochemistry and Petrology Branch, Washington ........ 1

Geophysics Branch, Washington ............... 1

Alaskan G eology Branch, Washington ........... 10

Terr. Dept. Mines, Juneau (P. H. Holdsworth, Ji. ) ...... 1

Terp. Dept. Mines, Ketchikan (A. E. Glover)........... 1

Terr. Dept. Mines, Anchorage (P.O. Sandvik)......... 1

Tert. Dept. Mines, College (L. L. Patton) .......... 1

Terip. Dept. Mines, Nome (D. Jones) .............. 1

G. O. Gates, San Francisco ................ 1

E. A. Youngberg, Juneau ................ 1

R. M. Chapman, Fairbanks .................. 1

V. E. MeKelvey, Washington ............... 1

L. R. Page, Denver.................... 1

R. P. Fischer, Grand Junction .............. 1

A. E. Weissenborn, Spokane ............... 1

TEPCO, Washington ................ 5

(Including master) 
Abstract ........................... 4

Introduction .................... 4

Geology...........................

Radioactivity studies .................. 7

Conclusions .......................... 10

References cited ................... 10

\section{TABLE}

Table 1. Data on selected samples from the Copper Creek copper lode prospect, Eagle district, east-central Alaska ..... 9

\section{ILLUSTRATION}

Figure 1. Sketch map of the Eagle district, Alaska ....... 5 


\section{RADIOACTIVITY AT THE COPPER CREEK COPPER LODE PROSPECT, EAGLE DISTRICT, EAST-CENTRAL ALASKA \\ By Helmuth Wedow, Jp. and Gene E. Tolbert}

\section{ABSTRACT}

Investigation of radioactivity anomalies at the Copper Creek copper lode prospect, Eagle district, east--central Alaska, during 1949 disclosed that the radioactivity is associated with copper mineralization in highly metamorphosed sedimentary rocks. These rocks are a roof pendant in the Mesozoic "Charley River" batholith. The radioactivity is probably all due to uranium associated with bornite and malachite.

\section{INTRODUCTION}

The Copper Creek copper lode prospect is located in the southwestern part of the Eagle district, east-central Alaska, about 60 miles west of the town of Eagle, which is near the international boundary (fig. 1). The prospect is on the right bank of Copper Creek about 6 miles above the creek's confluence with the Charley River.

The Copper Creek prospect has never been reported in Geological Survey literature although knowledge of it is widespread among prospectors in interior Alaska. It was staked and partially developed by the Hudson brothers in the early 1900 's, but since then has changed hands several times. The owner of the claim in 1949, Howard Sparks of Fairbanks, restaked the prospect in 1946, primarily on the 
GEOLOGICAL SURVEY

FIGURE ।

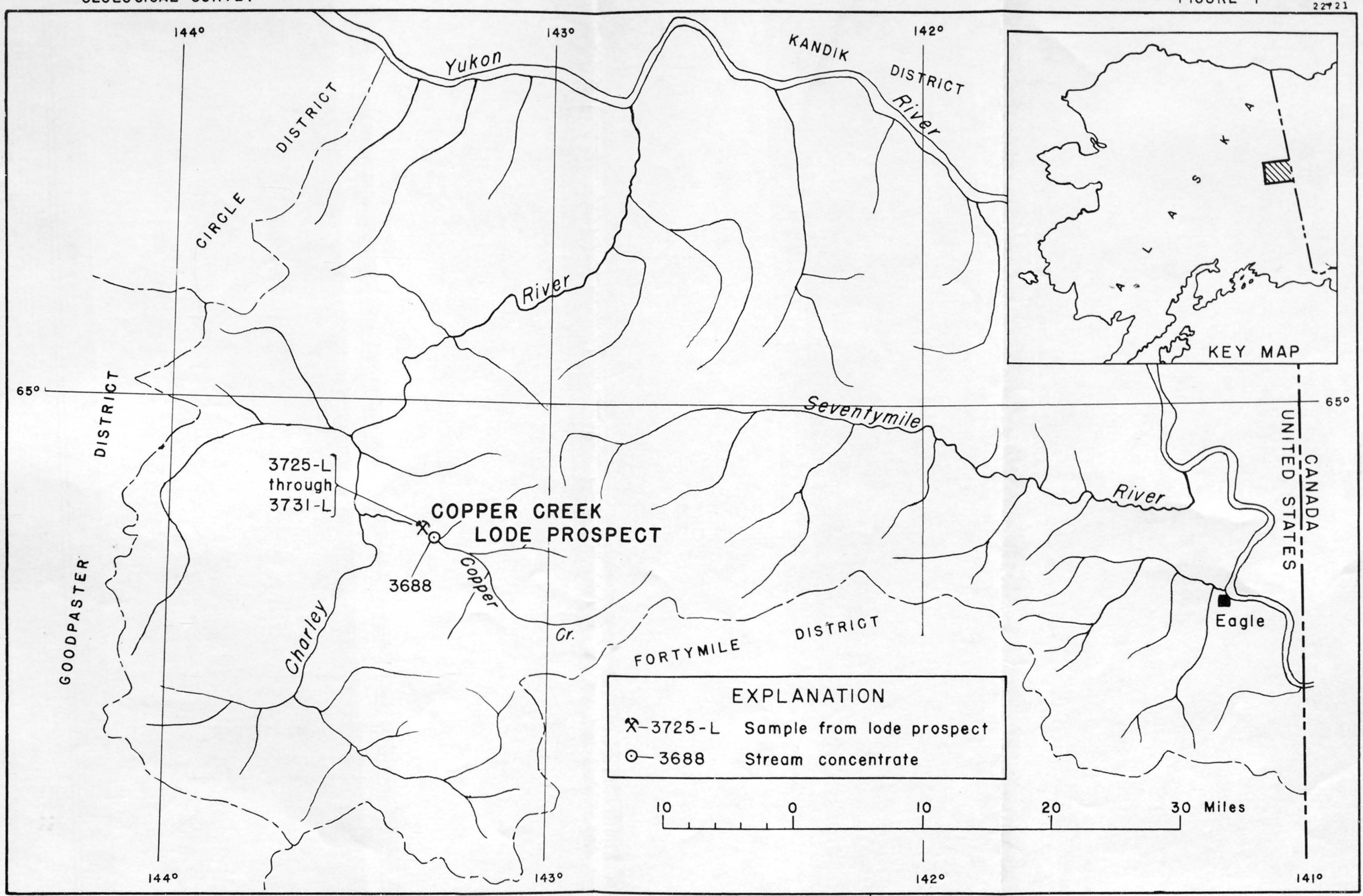


possibility that the gold, silver "lead „and tungsten content in addition to the copper might warrant further exploration.

The workings at the Copper Creek prospect consist of an adit in a cliffi-surface showing of copper ore. The portal is 10 to 15 feet above the level of Copper Creek and the workings extend 114 feet underground. The ore showings occur only in about the first 40 feet of the adit. Lack of understanding of a complex structure apparently caused the earlier prospectors to wander off the trend of the ore-bearing zone with the result that the last 60 feet of the adit is entirely in essentially barren rock.

The radiometric examination of the Copper Creek prospect was made as a side trip in connection with other radioactivity studies in the adjacent part of the Fortymile district (Wedow and Tolbert, in preparation). Transportation to the prospect was by a Sikorsky Model H5G helicopter furnished by Detachment B, Tenth Rescue Squadron, U. S. Air Force, based at Ladd Field, Fairbanks.

The examination was made on August 17, 1949. The authors were accompanied by George O. Gates of the Geological Survey and Howard Sparks, owner of the prospect. The statement below on the geologic setting of the prospect has been taken mainly from field notes by Gates.

This work was done on behalf of the Division of Raw Materials of the U.S. Atomic Energy Commission. 


\section{OFFICIAL USE ONLY}

\section{7}

\section{GEOLOGY}

The bedrock at the Copper Creek lode prospect, previously mapped in reconnaissance as Mesozoic(?) granite (Prindle, 1913, pl. 2; Mertie, 1937, pl. 1), consists of highly metamorphosed sedimentary rocks. These rocks are apparently part of a small (several sq, mi) roof pendant in the "Charley River" batholith and acted as a host for the deposition of the metallic minerals found in the prospect.

Tentative identiffications show lime-silicate rock and amphibolite as the two main lithologic types at the prospect. The bulk of the metallic minerals is in the lime-silicate rock, mainly along a contact with the amphibolite, although minor amounts of the metallic minerals are disseminated through both rock types but in dimminishing amounts away from the contact. Chalcopyrite, malachite and azurite are the chief metallic minerals at the prospect. Minor amounts of galena are present and traces of gold, silver and tungsten have been reported in assays.

\section{RADIOACTIVITY STUDIES}

The radioactivity of the rocks at the Copper Creek prospect was measured with a commercial model of a portable survey meter modified to accept both the standard 6-in. beta-gamma probe and a probe consisting of six 1-by 14-in. copper-walled gamma tubes connected in parallel.

The variation in radioactivity in the adit, as measured with the large gamma probe, is summarized as follows: 


\section{OFFICIAL USE ONLY}

8

Distance (ft) into adit from portal

$$
0-2
$$$$
2-18
$$

$18-32$

$32-40$

$40-44$

$44-48$

$48-54$

$54-114$
Radioactivity

(divisions on 2.0 scale)

10

8

10

$16-18$

12

10

8
Rock type

Lime-silicate rock and amphibolite.

Do.

Amphibolite

Lime-silicate rock. Lime-silicate rock with iron-stained fracture zones. Lime-silicate rock.

Do.

Do.

Testing with the 6-in, beta-gamma probe indicated that the radioactivity at the "portal" anomaly is localized around certain mineral groupings in the ore zone. At the "40-44" anomaly the radioactivity appears to be confined to iron-stained surfaces or zones along low-angle fractures or faults in the lime-silicate rock. Data on selected samples from both anomalies are summarized in table $I$.

As seen in table I the uranium in the samples from the Copper Creek prospect is concentrated mainly in material of less than about 3.0 specific gravity. This material consists mostly of wollastonite and reddish or yellowish calcite. It also contains minor amounts of galena and bornite, mostly as inclusions in some of the wollastonite grains. The bornite is slighily altered to malachite. The uranium apparently occurs as an impurity in the bornite and malachite.

The radioactivity of the placer concentrate (sample 3688, table I and fig. I) from Copper Creek is probably due mostly to thorium in trace amounts of monazite. 
Table 1.--Data on selected samples from the Copper Creek copper lode prospect, Eagle district, east-central Alaska (equivalent utanium analyses by members of the Alaskan Trace Elements Unit).

\begin{tabular}{|c|c|c|c|c|}
\hline Sample no. & $\begin{array}{l}\text { Equivalent ur } \\
\text { Unconcentrated } \\
\text { rock }\end{array}$ & $\begin{array}{l}\text { nium (percent) } \\
\text { Fraction less than } \\
3.3 \mathrm{sp} \mathrm{gp}\end{array}$ & $\begin{array}{l}\text { Fraction greater than } \\
3.3 \mathrm{sp} \mathrm{g}\end{array}$ & Remarks \\
\hline 3688 & $\rightarrow$ & $0.003^{a}$ & 0.013 b & $\begin{array}{l}\text { Concentrate from about } 50 \text { pounds of gravel } \\
\text { in Copper Creek about } 100 \mathrm{ft} \text { upstream from } \\
\text { lode prospect. }\end{array}$ \\
\hline \multicolumn{5}{|c|}{ "Portal"anomaly: } \\
\hline $3730-L$ & 0.032 & $0.044^{a, c}$ & $0.003 \mathrm{~b} /$ & $\begin{array}{l}\text { Grab sample from most padioactive spot on } \\
\text { east side of portal. }\end{array}$ \\
\hline $373 \mid=L$ & 0.001 & 0.003 & 0.002 & $\begin{array}{l}\text { Grab sample from slightly radioactive part } \\
\text { of ore zone on east side of portal. }\end{array}$ \\
\hline \multicolumn{5}{|c|}{ "40-44" anomaly: } \\
\hline $3725-L$ & 0.003 & 0.010 & 0.002 & $\begin{array}{l}\text { Grab sample of rock adjacent to most } \\
\text { radioactive iron-stained fracture zone. }\end{array}$ \\
\hline $3726-L$ & 0.006 & 0.004 & 0.003 & $\begin{array}{l}\text { Thip sample of I-foot layer above most } \\
\text { radioactive fracture. }\end{array}$ \\
\hline $3727-L$ & 0.003 & $0.012^{d}$ & 0.002 & $\begin{array}{l}\text { Chip sample of lafoot layer below most } \\
\text { radioactive fracture. }\end{array}$ \\
\hline $3728-L$ & 0.004 & 0.006 & 0.003 & $\begin{array}{l}\text { Grab sample of same fracture zone as } \\
\text { sample } 3725-\mathrm{L} \text { but about } 6 \mathrm{ft} \text { down dip } \\
\text { of fracture }\end{array}$ \\
\hline $3729-L$ & $-\infty-\infty \cos -\infty$ & not determined- & 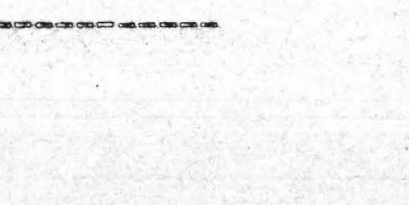 & $\begin{array}{l}\text { Specimen of rock immediately below fracture } \\
\text { in sample } 3725-\mathrm{L} \text {; radioactivity appears to be } \\
\text { confined to } 0.1 \mathrm{ft} \text { of rock immediately } \\
\text { adjacent to fracture. }\end{array}$ \\
\hline \multicolumn{5}{|c|}{$\begin{array}{l}\text { a/ Fraction less than } 2.8 \mathrm{sp} \mathrm{gr} \\
\text { b/ Fraction greater than } 2.8 \mathrm{sp} \mathrm{gr} \\
\text { c/ Contains } 0.058 \text { percent } U \text { as determined by F. S. Grimaldi, Washington Trace Elements Laboratory } \\
\text { d/ Contains } 0.009 \text { percent } U \text { as determined by F. S. Grimaldi, Washington Trace Elements Laboratory }\end{array}$} \\
\hline
\end{tabular}




\section{OFFICIAL USE ONLY}

10

\section{CONCLUSIONS}

Minor amounts of padioactive materials are associated with copper ores at the Copper Creek prospect in the Eagle district where a small roof pendant in the "Charley River" batholith appears to be highly mineralized. The radioactive minerals are bornite and malachite, in which uranium occurs as an impurity. Because of the limited time available for the examination of the prospect, reconnaissance of most of the roof pendant area was not undertaken. It is possible that greater concentrations of uranium may occur in or immediately adjacent to the area of the roof pendant.

\section{REFERENCES CITED}

Mertie, J. B., Jr., 1937, The Yukon-Tanana region, Alaska: U. S. Geol. Survey Bull. 872.

Prindle, L. M., 1913, A geologic reconnaissance of the Circle quadrangle, Alaska: U. S. Geol. Survey Bull. 538.

Wedow, Helmuth, Jr., and Tolbert, G. E., in preparation, Reconnaissance for radioactive deposits in the Fortymile district, east-central Alaska, 1949: U. S. Geol. Survey Trace Elements Investigations Report 196; title subject to change. 